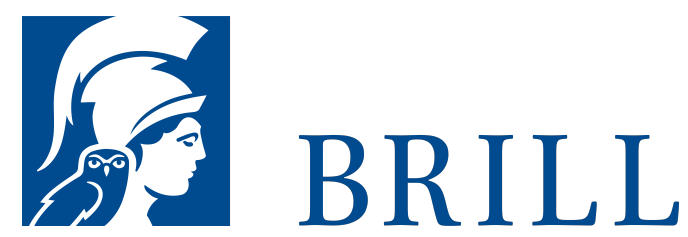

\title{
Die Acta Alexandrinorum im Lichte neuerer und neuester Papyrusfunde
}

Authors: Natalia Vega Navarrete and Natalia Vega Navarrete

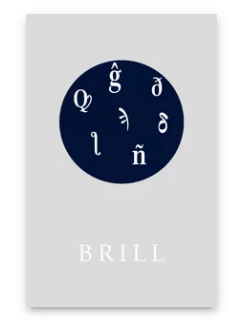

Pages: XII +395 Seiten, $4 \mathrm{~s} / \mathrm{w}$ Abb., 2 s/w Tab.

Language:

German

Subjects:

Ancient History, Classical Studies

Publisher: Brill |

Schöningh

Series:

Sonderreihe der Abhandlungen

Papyrologica

Coloniensia

E-Book (PDF)

Released online:

22 Jun $202 \mathrm{O}$

ISBN: 978-3-

657-78863-7

List price

Paperback

Publication date: o8 Sep 2017

ISBN: 978-3506-78863-4 
For more information see brill.com

Order information: Order online at brill.com +44330 333 0049 | customerservices@brill.com Submission information: brill.com/authors

Titles published by Brill | Fink, Brill | mentis or Brill | Schöningh: +49(o)715413279216| brill@brocom.de 